Post-print de:

Rodríguez-Hernández, Jesús \& González-Álvarez, David (2021): Luna Celta: historical re-enactment, central Spain: Iron Age alive!, International Journal of Heritage Studies, 27:2, 134-150, doi: https://doi.org/10.1080/13527258.2020.1771749. ISSN: 1470-3610

\title{
Luna Celta historical re-enactment, central Spain: Iron Age alive!
}

\author{
Jesús Rodríguez-Hernández a * ORCID: http://orcid.org/0000-0002-1243-3642 \\ David González-Álvarez b ORCID: http://orcid.org/0000-0001-7021-9321 \\ a Department of Prehistory, Ancient History and Archaeology, \\ Complutense University of Madrid, Madrid, Spain; \\ * Correspondent author.e-mail: jesusrodriguez@ucm.es \\ ${ }^{\mathbf{b}}$ Institute of Heritage Sciences (Incipit), Spanish National Research \\ Council (CSIC), Santiago de Compostela, Spain
}

\begin{abstract}
:
Historical re-enactments can be understood as contemporary manifestations of popular culture. Thus, such events become outstanding social contexts for exploring the social and political foundations of 'bottom-up' narratives concerning the past. In this paper, we analyse the Luna Celta festival in Solosancho (Ávila province, Spain) as a case study for considering the public reception of the Iron Age in this region. For this purpose we have constructed our theoretical and methodological approach based on public archaeology and heritage studies literature. Materiality and performance as resources deployed by amateur actors are revealed as extremely effective ways of disseminating and naturalising non-academic discourses on the Iron Age, according to our ethnographic account. In contrast, scientific initiatives promoted by archaeologists show more limited success in reaching lay audiences. On-going heritagisation processes around local Iron Age sites (such as the oppidum of Ulaca) and the Vettones are also analysed, assessing the diverse agendas of the different stakeholders involved in the festival.
\end{abstract}

KEYWORDS: Cultural heritage studies; public archaeology; public participation in heritage; archaeology and tourism; cultural heritage resource management

\section{ARTICLE HISTORY}

Received: 4 February 2020

Accepted: 14 May 2020

Published online: 31 May 2020

\section{Introduction}

Historical re-enactments are a growing phenomenon throughout Europe and the West. Every year more of these festivals are organised and more people become involved as participants, organisers and spectators (Appleby 2005; Raposo 2008; Daugbjerg 2014; Kobiałka 2014). Spain is also seeing expansion of these events (Busquets Artigas 2009; Rojas Rabaneda 2011; Herrero Acosta and Ayán Vila 2016), especially those related to the Iron Age (Burillo, Burillo, and Segurado 2009; Alonso González and González Álvarez 2013; Jimeno Martínez 2013), which roughly corresponds to the first millennium BC on the Iberian peninsula. New historical reenactment events are springing up everywhere, attracting increasing numbers of visitors and receiving greater attention from the media. They are also having a positive impact on the local economies of the places in which they are held, as indicated by diverse studies into Spanish reenactment events (Pena Castro 2004; Rojas Rabaneda 2010; Folgado Fernández, Hernández Mogollón, and Campón Cerro 2016; Fernández Ramos et al. 2018). 
However, little attention has been paid to re-enactments by social scientists, particularly among archaeologists and heritage management experts (some examples in Appleby 2005; Agnew 2007; Cortadella 2011; Daugbjerg 2014; Kobiałka 2014). Most of our colleagues consider historical re-enactments as rather quaint, but poorly informed events in scientific terms. Therefore, most detest them, deny their cultural value and refuse to get involved. However, tourism entrepreneurs, local politicians, private companies and advertising agencies all recognise their importance and involve themselves with their own agendas, while archaeologists remain out of the picture (Alonso González and González Álvarez 2013).

In this paper, we will reflect on historical re-enactments as contemporary cultural representations (Holtorf 2005b; De Groot 2009). We consider these festivals as social contexts in which the public can engage with cultural landscapes and heritage and build 'bottom-up' historical and archaeological narratives. These contexts primarily serve for the publics 1 to have fun and enjoy themselves, expressing and negotiating contemporary identities, and promoting tourism and business. In addition, we will briefly point out some of the issues that we, as archaeologists, should be aware of with regard to the nature of these festivals. Finally, we will explore the possibilities offered by historical re-enactments for the dissemination of archaeological narratives in a more inclusive way, reflecting on multivocality, multiculturalism, and Open Science.

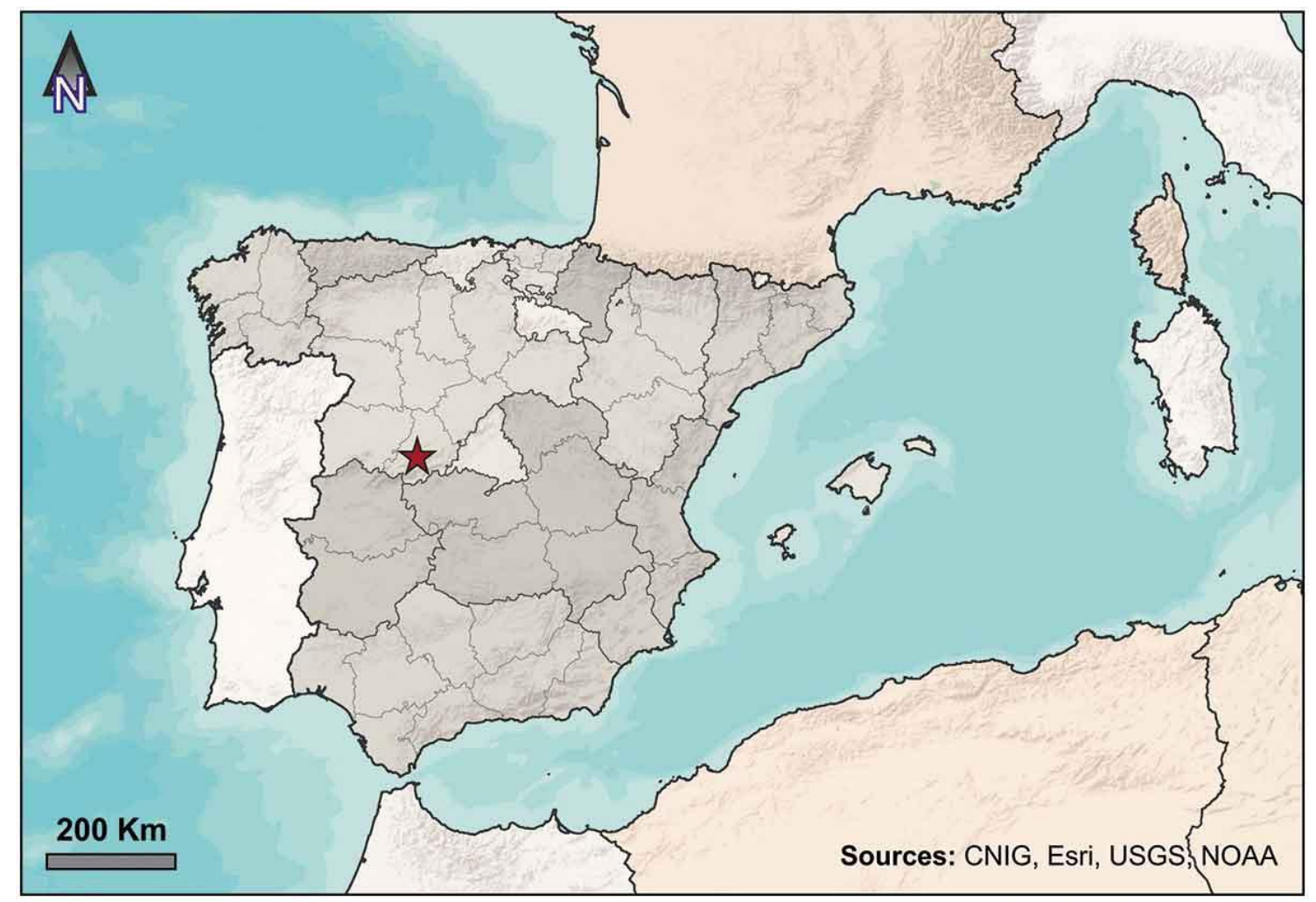

Figure 1. Map of Spain with the location of Solosancho (Ávila) (drawn by David González-Álvarez)

To do this, we will examine the Luna Celta festival (Celtic Moon festival) in Solosancho (Ávila province, Spain) as our case study (Figure 1). This festival is one of the most outstanding historical re-enactment events in Spain (Ruiz Zapatero and Salas Lopes 2008, 416-417). It has been held for more than ten years, involves thousands of people, taking into account the organisers, participants and members of the public, and is linked to one of the most impressive and best-known Iron Age sites on the Iberian Peninsula: the oppidum of Ulaca (Ruiz Zapatero 2005a). After conducting extensive archaeological research into this singular archaeological site (Álvarez-Sanchís 2005a; Álvarez-Sanchís et al. 2008; Rodríguez-Hernández 2019), a research 
team from the Complutense University of Madrid is investigating how local communities engage with the cultural landscapes related to Iron Age oppida, and how tourism and land-use policies mediate in the public perception of long-term changes within those landscapes (Álvarez-Sanchís and Rodríguez-Hernández 2016; Tully et al. 2019; Moore, Guichard, and Álvarez-Sanchís 2020).

\section{The reception of the Iron Age in the present}

The pre-Roman past constitutes an essential reference for contemporary identities in several regions of Spain, especially in relation to the rise in nationalist and regionalist discourses (e.g. Díaz Santana 2002; Ruiz Zapatero 2006; Marín Suárez, González Álvarez, and Alonso González 2012). In the case of Ávila, the Iron Age communities - called the Vettones by the Romans - play an important role as a 'prestige reference' for the region's present-day population. Some of its inhabitants feel a sort of self-identification with those Iron Age peoples, who are also used by the regional government and public agencies to promote tourism. Local companies use archaeological references relating to the Vettones in their branding and marketing strategies and as a source of 'cultural labelling' for business purposes (Ruiz Zapatero and Salas Lopes 2008).

These two main aspects could be behind the growing public interest in re-enactment festivals in Spanish regions such as Ávila. However, for most of the people involved, re-enactments are mainly festive celebrations in which outstanding events from the past are brought to life through different types of performance. Thus, historical and archaeological narratives constitute a sort of background music for a big party. This means that there may be people participating in the re-enactments who possibly pay no attention to archaeological narratives at any other time in their entire lives. As such, self-experience and performativity could be considered here as a unique opportunity for archaeologists to engage with them and disseminate their academic interpretations of the Iron Age and ancient cultural landscapes. Consequently, re-enactments should receive greater attention in the context of public archaeology as a line of research dealing with the interaction between archaeological heritage, archaeology as a discipline, and contemporary society (Schadla-Hall 1999; Merriman 2004; Moshenska 2017).

The archaeological site of Ulaca is located in a rural part of the so-called 'empty (or emptied) Spain' (Del Molino 2016), which is suffering from depopulation and a huge decline in the primary sector (Fewster 2007). Tourism has emerged as an alternative economic activity and European Structural Funds have been allocated to promote these initiatives. Thus, in the last two decades, the regional government has developed an extensive programme of activities designed to promote archaeotourism in Ávila province. In 2001, the successful 'Celts and Vettones' exhibition was held in Ávila (Almagro-Gorbea, Mariné, and Álvarez-Sanchís 2004). It had more than 100,000 visitors and became an outstanding cultural and tourist reference for the city. In fact, this exhibition can be considered as an important milestone in the touristification of Iron Age monuments in Ávila, enhancing the public interest in the legacy of the pre-Roman Vettones. This initial boost was consolidated with a permanent Vettonian culture exhibition centre set up at the regional government headquarters in 2005 (Álvarez-Sanchís and González-Tablas 2005). The same provincial institution also sponsored two more temporary exhibitions: 'The discovery of the Vettones. The finds from the National Archaeological Museum' (AA. VV 2005) and 'Echoes of the Mediterranean: the Iberian world and the Vettonian culture' (Barril Vicente and Galán Domingo 2007).

Within this same context, some of the main Iron Age sites in the region have been excavated and restored, along with a series of investments to improve their presentation and public accessibility within the framework of the European INTERREG III-A project (2003-2005) (Fabián García 2008). In the case of Ulaca, it is worth mentioning the archaeological excavations carried out in the cemetery area (Álvarez-Sanchís et al. 2008; Rodríguez-Hernández 2019), as well as the reconstruction of some stretches of the impressive stone walls around the main entrance to the oppidum (Collis 2008, 67). Likewise, specific actions have been carried out on some of the 
verracos (Fabián García 2004, 35-36), the stone sculptures representing bulls and male pigs erected by the Vettones (Álvarez-Sanchís 2003b, 215-294; Ruiz Zapatero and Álvarez-Sanchís 2008). This has led to the consolidation of a tourist itinerary taking in these sites and other important enclaves in nearby regions of Salamanca in Spain and Região do Norte in Portugal (Ser Quijano 2006). In the province of Ávila, a website was launched (https://www.castrosyverracosdeavila.com) and a series of archaeological guides (e.g. Ruiz Zapatero 2005a; Álvarez-Sanchís 2005b, 2006; Fabián García 2006), including a children's guide (González-Tablas and Mateos Benito 2004), were published to promote and disseminate this route. All these actions have led to a notable increase in the number of visitors to these sites, between 43\% and 75\% from 2001 to 2006 (Fabián García 2008, 434).

This boom in the dissemination of the protohistoric remains of western Iberia and the processes of popular construction of local identities in the general context of globalisation could, according to Ruiz Zapatero and Salas Lopes $(2008,410-411)$, explain the emergence of a popular 'Vettonism'. This phenomenon uses the most striking elements of the pre-Roman past to build identities and 'prestige references' in Ávila. In the last two decades, the famous verracos have become icons that have served for designing logos, small figures carved in granite, sweets, or even municipal coats of arms, such as the one designed for Solosancho (Fewster 2007). In the same way, the Iron Age horse-shaped brooches found at the nearby site of Las Cogotas (Cardeñosa, Ávila) are reproduced in the tourism logo of the regional government, as well as in the Vettonia Hockey club logo. Likewise, the protohistoric past in this area has inspired novels, such as The Ulaca Night (Vicente Toribio 2004), comics (Ruiz Zapatero and Salas Lopes 2008, 420) and songs, such as Ulaka, the last oppidvm (https://keltikahispanna.bandcamp.com/album/karpetovettonika-cd-r-2014). In addition, a number of re-enactment festivals have emerged around the main pre-Roman sites of western Iberia, including Luna Celta in Solosancho (Ávila).

The Luna Celta festival began in 2005, one year after the last of the archaeological excavations at the Ulaca cemetery (Álvarez-Sanchís et al. 2008; Rodríguez-Hernández 2019). During the first three editions of the festival, talks on different Iron Age themes given by various archaeologists were included in the official programme. However, the archaeological lectures were replaced by 'Celtic' folk music concerts from 2008 onwards. Since then, the festival has continued to grow. In fact, the success of Luna Celta has led to the launching of similar festivals in nearby towns with Iron Age heritage. They include the Lugnasad festival in La Mesa de Miranda (14 editions), the Celtic Festival in El Raso (9 editions) and the Vetton festival in Yecla la Vieja (between 2005 and 2013).

\section{Objectives and methods}

We conducted an ethnographic exploration of the Luna Celta festival during the 2016 and 2017 editions, following up a wider study of the contemporary reception of the Iron Age in central Iberia in connection with the Vettones. The goals of this paper are (i) to examine the potential of this festival for engaging local communities with the cultural landscapes around the oppidum of Ulaca, (ii) to assess the role of the Iron Age as a reference for shaping contemporary identities, and (iii) to explore the relations between historical re-enactment festivals, archaeological research and tourism in central Spain.

Previous research undertaken by one of us on re-enactment festivals in the north-western Spain between 2010 and 2013 (Alonso González and González Álvarez 2013; González Álvarez and Alonso González 2013) served as a starting point for designing our current investigation in Ávila. The ethnographic account of the 2016 and 2017 editions of Luna Celta constitutes the basis for this investigation. Following Meskell's (2005) proposal to hybridise anthropological and archaeological methods, we followed a multidisciplinary approach embracing recent suggestions to develop archaeological ethnographies (Hamilakis 2011). 
Before our fieldwork, we compiled social and cultural information about Solosancho and the surrounding area through the analysis of available data. Particularly, we explored the origins of the re-enactment festival and past editions, mainly examining the official programmes and brochures produced by the re-enactment organisation, the press coverage on previous editions and some video footage available online. Due to the personal proximity to the study area by one of us (natural from the city of Ávila) and our previous archaeological experience at the site of Ulaca, we were familiar to the research context before this study began.

Within the 2016 and 2017 editions, the authors attended the full programme of the Luna Celta festival to conduct ethnographic research. Without a predetermined or rigid scheme, we gathered data using semi-structured interviews with some of the main agents involved in the organisation of the re-enactments, in addition to informal interviews and conversations with a number of participants and attendees (Sørensen 2009; King and Horrocks 2010). During the interviews, we first asked about the interviewees' reasons behind their involvement in the reenactment, avoiding any judgemental tone in our questions. Granting them space for the free expression of their opinions, we also addressed key themes for our investigation, such as their identification with the historical narratives displayed at the festival, their concerns about authenticity within the re-enactment, or their impressions about the festival impact on tourism or heritage preservation and the relevance of the event for the local community. We paid particular attention to the materiality deployed in the village of Solosancho, to the participants' outfits, and to the discourses and narratives behind the main events and theatrical performances at the festival. We documented so through photography and video, in addition to take notes about the main acts and settings. Besides, we enquired re-enactors about the origin and significance of their clothes and the items displayed by their tribes. Thus, we observed the role that materiality played in the naturalisation of the narratives produced and disseminated during the re-enactment. We also analysed the coverage of the re-enactments in the regional media, and we looked at their economic impact on different levels.

Indeed, analysing how the pre-Roman societies are collectively remembered is one way of obtaining a better understanding of our own (popular) culture and how to engage with communities that remember their past (Holtorf 2005b, 3-5).

\section{An ethnography of the 2016-2017 editions}

The Luna Celta re-enactment festival is organised by the Solosancho local municipality with the support of the regional government, the Asociación Cultural Ulaka (Ulaka Cultural Association), and many local residents. During the re-enactment, local people and visitors dress as Vettones and recreate historical events related to the Iron Age, mainly battles, ritual ceremonies, feasts and parades, in a similar way to other Spanish and European re-enactment events (e.g. Appleby 2005; Ruiz Zapatero 2005b; González Álvarez and Alonso González 2013; Kobiałka 2013). Although they attempt to represent the past as accurately as possible, we should not forget that enjoyment is the main aim for most of them. In the 15 editions of the festival there have been representations of combats, funerals, weddings, craft demonstrations, etc. Complementary activities, such as archery, climbing and Iron Age weapon-making workshops, have also been organised. Among all these activities, we can examine some of the issues under consideration and integrate our ethnographic accounts into further discussion within this article.

\subsection{Theatre - Ulaca}

The re-enactment festival begins on Friday night with a 'Celtic' folk music concert (Figure 2(a)) and a play performed by local actors on the Ulaca altar. The play is based on a different theme every year and the script follows archaeological and historical information gleaned by the scriptwriters from outreach books written by archaeologists (Álvarez-Sanchís 2003a; Almagro- 
Gorbea, Mariné, and Álvarez-Sanchís 2004), as well as from the internet (mainly Wikipedia, amateur blogs and New Age pan-European Celtic narratives ranging from Irish legends to Tolkien's fantasy world). The performance of this play generates controversy among archaeologists, since the majority of our colleagues express their concerns regarding the conservation of the site and the integrity of the Ulaca altar itself. In the 2016 and 2017 editions, the play at the top of the Ulaca site brought around 3,000 people to the Iron Age oppidum (according to the testimonies of the festival organisers published in the media). The audience climbed the steep slopes of the Ulaca hillfort for more than half an hour before descending in the middle of the night. However, we must bear in mind that, since the actors are local, at least a part of the audience is not there to learn about the Vettones, but to see their relatives and friends performing.
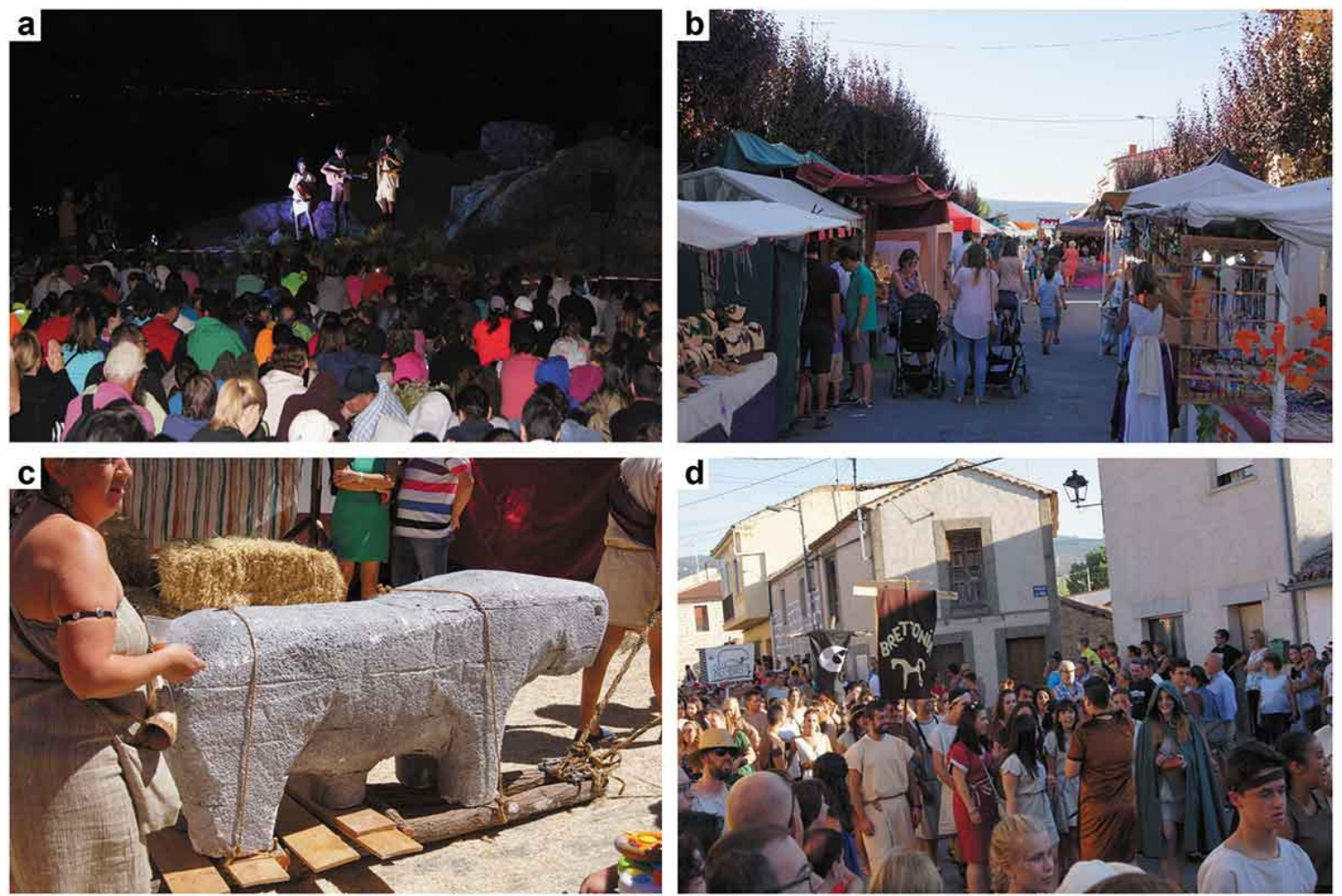

Figure 2. View of some of the activities carried out in the different areas of the festival. (a) 'Celtic' folk music concert performed on the Ulaca altar. (b) People walking in the Celtic-Vetton market. (c) Reenactors carrying a replica of an Iron Age sculpture through the market. (d) Parade of the Bretonnia tribe (photographs by Jesús Rodríguez-Hernández)

Although the script of the play changes every year, there are several recurring themes that are relevant to our investigation. Firstly, the role of women in the past has been highlighted in the more recent plays (2016-2018). Interestingly, the patriarchal nature of the Vettonian society is condemned and the women are linked to the home and the 'maintenance activities' (e.g. Picazo Gurina 1997; Montón Subías and Sánchez Romero 2008): 'it was a patriarchal society, women did not matter'; 'she will inherit the power of her father. Impossible! She is a woman, her role is in the house'; 'women do not leave the hillforts'. 2

Secondly, the magical nature of Ulaca is a recurrent topic addressed in the plays performed on the altar. In the performances, the site appears to be endowed with an aura and a special energy (Holtorf 2005b, 106-09): 'this place is magical, it is as if nature speaks to us'; 'a place of connection with the powers of the supernatural'; 'this place has a special energy'. 
The warrior ethos of pre-Roman communities such as the Vettones is another frequent element in the narratives recounted by the Luna Celta plays. The relevance of this topic perpetuates the view of these communities as warlike groups, paying heed to the descriptions given by the classical sources (Sánchez Moreno 2000, 26-29). In this respect, we may recall some of the statements heard in the 2016 and 2017 Luna Celta performances: 'in the Iron Age they were killing each other'; 'war is the natural state of the peoples'; 'we are a brave and warrior people'.

Moreover, the 2016 play was performed in an ambiguous chronological context, between the past and the present. This literary resource allowed the director and the scriptwriter to explicitly introduce current issues, such as pacifism, xenophobia, mobile phone harassment by controlling partners, veganism and reggaeton ('sexist and ultra-sexual music that denigrates women'), while performing an Iron Age-based story.

\subsection{The market - Solosancho}

During the weekend, a large market is held along the main street of Solosancho and is the focus of the festival (Figure 2(b)). It consists of stalls full of regional products, jewellery, crafts (ranging from leather to aromatic candles), etc. and bars serving chorizo and ham sandwiches, in addition to enough beer to keep the thousands of people who visit and take part in the re-enactment festival well hydrated. A market regulation states that the decoration of the stalls, the sellers' dresses and the music 'must be Celtic-Vetton, and non-medieval' (accessible on the Solosancho local council website section devoted to the festival: https://www.aytosolosancho.es/?s=mercado). In fact, several tribes were sanctioned during the 2016 edition of the re-enactment because they played rock music on their stalls, resulting in them being banned from the next edition of the festival market, according to the testimonies gathered during our fieldwork.

The opening of the market is celebrated with a parade of the different local tribes, who carry their corresponding banners and other characteristic Vetton elements, such as a replica of one of the verracos located in the Ulaca area (Figure 2(c)). All this is enlivened with 'Celtic' folk music played by bagpipers and percussionists, while some people dance and juggle while marching at the front of the participants' crowd. This theatrical act is repeated several times throughout the weekend, allowing the public to contemplate the diverse outfits of the tribes and their embodied Vettones performance.

A contest of tribes has been held in recent editions of the festival, with the aim of rewarding the best groups of re-enactors and encouraging local people to get involved in the festival. Tribes are made up of families and groups of friends. For example, in the 2017 edition, the Bretonnia tribe was made up of 21 people from the same village, Baterna, about $3 \mathrm{~km}$ from Solosancho (Figure 2(d)). Different aspects are evaluated by the jury in the tribes contest: the originality of their dress and complements (hairstyle, jewellery, beads, shoes, body paintings, etc.), their active involvement in the festival throughout the weekend (e.g. their enthusiasm during the parades across Solosancho), the historical accuracy of their outfits, and the short speeches given on the main festival stage by a delegate from each tribe (Figure 3(a)). Those speeches address different aspects of the tribes, such as their alleged origins, their connection with historical events, and how much fun they are during the re-enactment festival. Certainly, the most recurrent theme in the tribes' discourses during the period of our fieldwork was the resistance against the Roman invasion, led by their warrior and Druid leaders:

Today our worst omens have been fulfilled. Those who call themselves Romans are coming, they want to conquer our lands, make us their slaves, impose their laws and customs on us and destroy everything we have achieved so far. But we will not allow it because our people will always be free. We must be united to prevent them from crossing our sacred walls [...]. I, as a Druid, will use my magic so the gods are on our side. The children and the elderly will prepare 

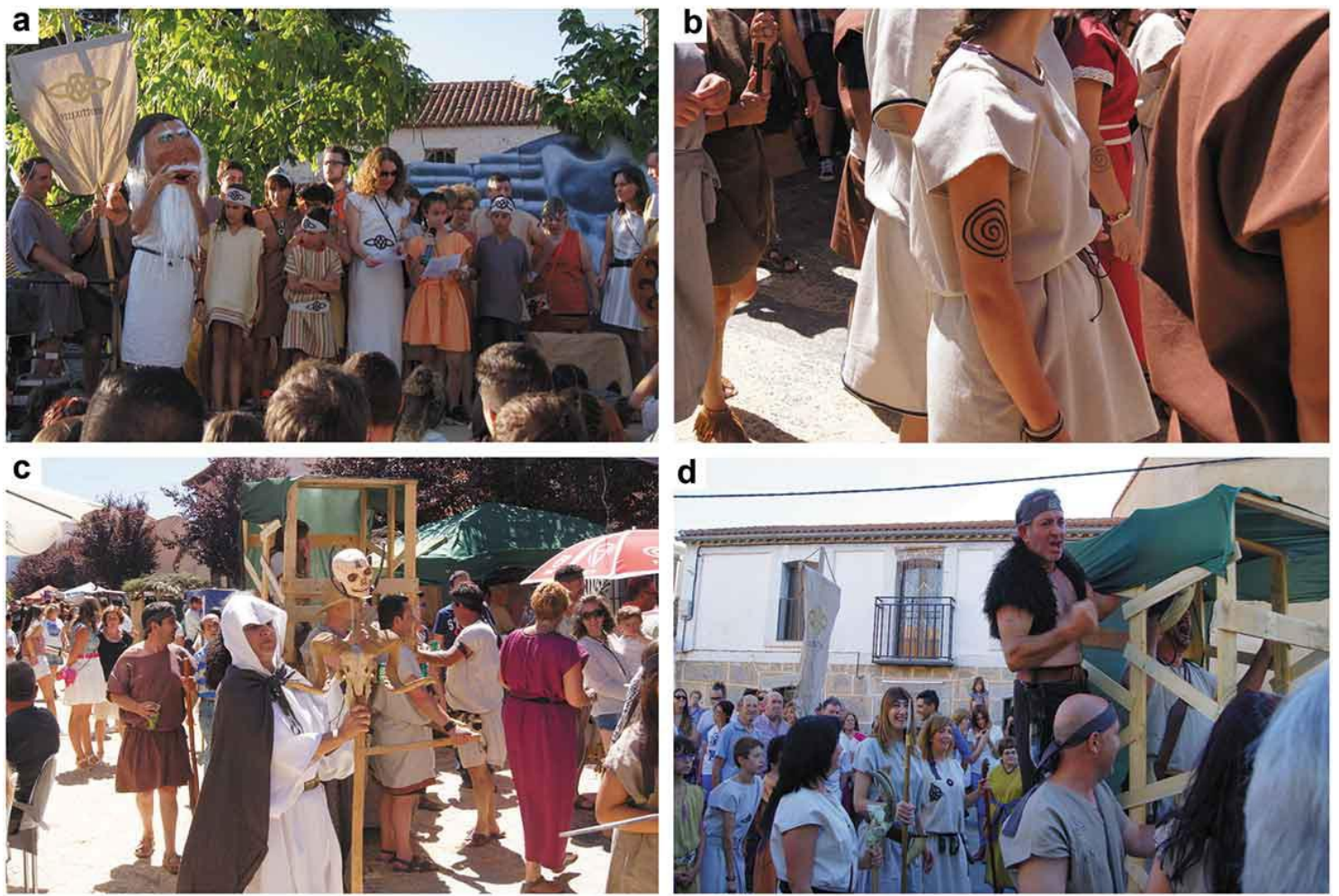

Figure 3. Different body technologies displayed at the re-enactment. (a) The Veleaittones tribe wearing a band decorated with a Celtic-inspired knot. (b) Re-enactors with spirals painted on their arms. (c) A female Druid with her macabre staff. (d) An indigenous chief in his parade 'chariot' (photographs by Jesús Rodríguez-Hernández)

The Vetton re-enactors' outfits are mainly made of cloth with leather ornaments, although furs are sometimes used. Body painting and make-up are the other essential body technologies used by the re-enactors to represent Iron Age characters (Figure 3(b)). Among the embroidered or painted symbols, those relating to the Celtic world (triquetras, triskelia, trees of life, spirals and different types of knots) stand out, although other types of symbols are also adopted, such as yin and yang. Homogeneity prevails within each tribe as a clear material mechanism for reinforcing their sense of self-belonging and their group identity. Therefore, there is no role or gender differentiation among them. Only certain prominent characters escape such homogeneity, such as the Druids (Figure 3(c)) or the indigenous chiefs (Figure 3(d)), who accentuate the distinct role they play within the tribes through materiality.

As in other similar re-enactment festivals, the accepted forms of clothing, body painting, music, practices and discourses are supported by a broad 'common sense' derived from the cultural representations of the Celts and Barbarians in contemporary Europe (González Álvarez and Alonso González 2013). Thus, the models followed are those of comics such as Asterix, Irish and Nordic mythology, and films such as Braveheart, The Lord of the Rings and Conan the Barbarian. 3 The contrast of these material traces with the commonly accepted representations of the Roman stuff (as civilised representations different to the Celts or Barbarians) constitutes a clear observation on the characterisation of the tribes participating in Luna Celta (Kristiansen 1996; Hingley, Bonacchi, and Sharpe 2018).

Throughout the weekend, different sports activities are organised for children (archery, zip-line and climbing), in addition to Celtic storytelling by elves (Figure 4(a)). Other series of amusements 
completes the festival programme, including having fun on a Viking drakkar as a swing! (Figure $4(b))$. During the festival there are parades of weird characters, such as fauns or elf warriors, Iron Age combat exhibitions (Figure 4(c)), evening concerts and sound and light shows with jugglers playing with fire (Figure $4(\mathrm{~d})$ ).
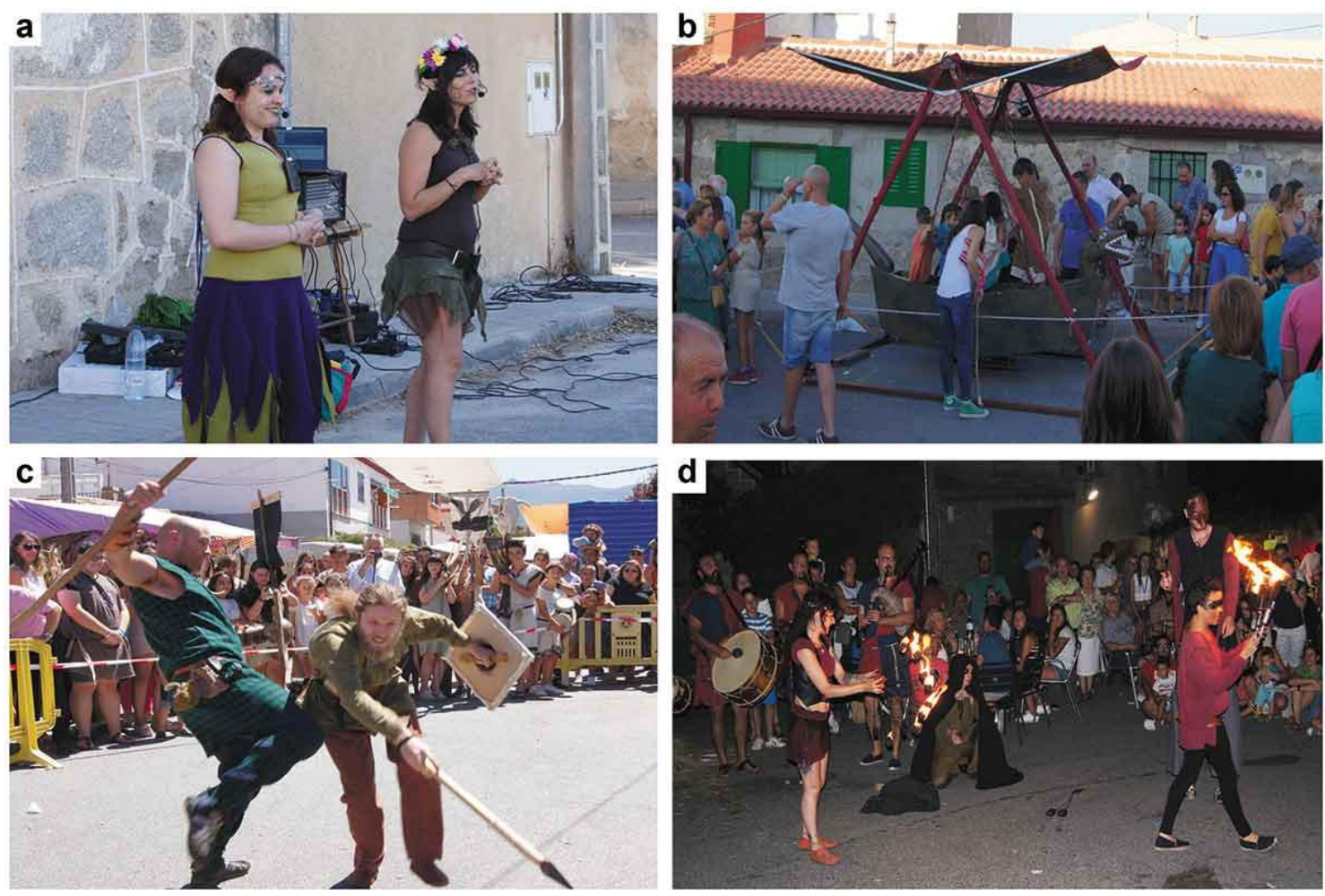

Figure 4. Complementary activities during the weekend. (a) Storytelling by forest elves. (b) A Viking ship swing. (c) An Iron Age combat display. (d) Evening concert and jugglers playing with fire (photographs by Jesús Rodríguez-Hernández)

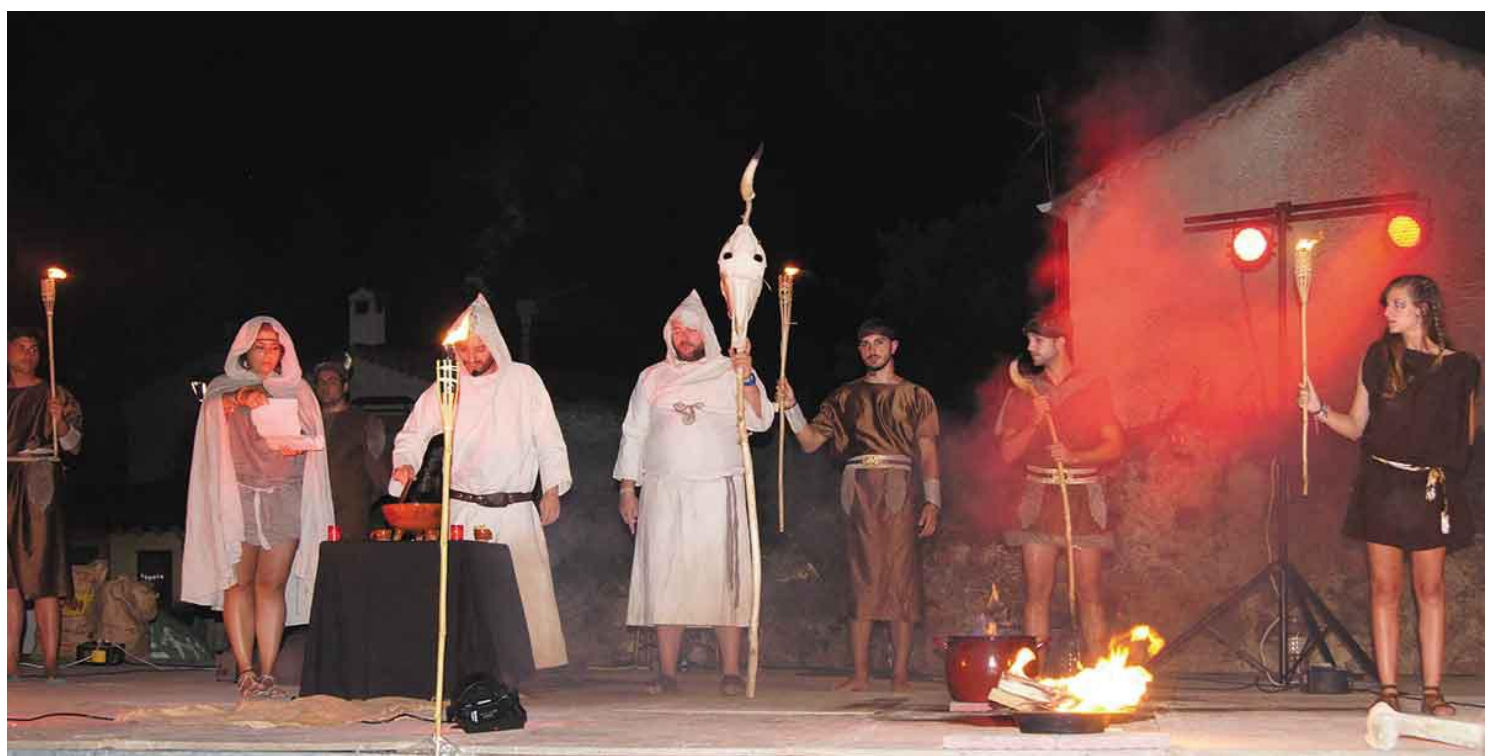

Figure 5. The Druids preparing a Queimada (photograph by Jesús Rodríguez-Hernández)

The festival ends with the preparation of a queimada (an alcoholic beverage made with liquors, wine, fruit and soda), intoning the traditional spell in Galician language to scare away the meigas 
or witches of popular mythology in north-western Spain. Although sometimes believed to be an old Celtic tradition, the origin of this ritual is relatively recent, since it can be placed in the 1950s as an exotic spectacle performed for tourists and visitors in Galicia (Figure 5) (González Reboredo 2001, 229-30).

\subsection{Beyond the event}

As with other popular events, we cannot separate local/regional politics from this historical reenactment. For example, the mayor of Solosancho at the time of our fieldwork, a member of the Partido Socialista Obrero Español (the main Spanish progressive party), was the main promoter of the festival. For this reason, he was always at the head of any ceremony during the re-enactment while we conducted fieldwork at the 2016-2017 editions. There was antagonism between the different political parties, as the regional institutions in Ávila were controlled by the Partido Popular (the main Spanish conservative party). This led to complicated situations when they met at the festival, as we saw during the 2016 edition. Then, the local and regional conservative politicians came on stage at the tribes contest without being dressed as Vettones. The local festival organisers were against this as they saw it as a clear undermining of the 'authenticity' and 'accuracy' pursued by the festival. However, the conservative politicians, including local Partido Popular representatives, were reluctant to allow full prominence to be given to the local mayor, as he was the central actor wearing Vetton warrior outfits on the main stage, in front of a big crowd.

The Luna Celta festival is well covered by the local and regional media, meaning that the narratives behind the re-enactment and the materiality deployed at the festival are disseminated beyond the visitors and participants. Television and newspapers cover the festivities, celebrating local Vetton pride and the joy of the local inhabitants of Solosancho. The festival also inspired the novel Ulaca. An Amazing Night (Miranda Viñuelas 2008). The popularity attained by Solosancho and Ulaca has been taken advantage of by the town council to launch other activities throughout the year: the Ulaka Summer Camp for children aged between 5 and 17 (8 editions, starting in 2012), the Ulaca tourism seminar for local tourism entrepreneurs (4 editions, starting in 2016), and the Celtibike cycle race (3 editions, starting in 2017) with around a hundred participants. Thus, Ulaca has literally become a brand (Holtorf 2007) based on Iron Age references! Within this context, there is no doubt that the Luna Celta re-enactment event was a turning point in the heritagisation (Smith 2006) of the Iron Age in Ávila, particularly in Solosancho, where the Ulaca archaeological site and the past related to the Iron Age are becoming commodified (Comaroff and Comaroff 2009). As the mayor of Solosancho told us in an interview during the 2016 edition, 'Luna Celta is a fundamental pillar for the emerging tourism sector in our municipality'. We can connect these observations with Crang's (1996) reflections on tourism and authenticity. Indeed, references to the Iron Age Vettones become a prestigious reference in the cultural labelling of villages like Solosancho as an attractive touristic destination.

For the residents of Solosancho, the Luna Celta festival has also become a pivot of neighbourhood socialisation at the local level, revealing the potential of archaeological heritage for empowering local communities and enhancing self-acknowledgement and recognition of local landscapes (Ayán Vila 2014). As one of the members of the Mulacos tribe mentioned in a television interview in 2017 ' [the Luna Celta means] fun, having a good time and uniting all the people of the village'. 4 Almost all the inhabitants (both permanent and temporary) reserve that weekend to be in the village and to see their family and friends at least once a year while enjoying the festive atmosphere: 'The Celtic market at Solosancho is amazing [...], as well as the night at Ulaca. It is a magical weekend [...] to have a good time' (Druid of the Bretonnia tribe in a television interview in 20165 ). The popularity of the re-enactment festival has even overshadowed the local patron saint's festival in Solosancho, held on 6 May in honour of San 
Juan ante Portam Latinam. Some local people who live outside the village told us that they prefer to take holidays from their jobs and come to Solosancho for the re-enactment festival, rather than the local patron saint's festival inspired by Christian religious traditions!

\section{Discussion}

\subsection{Archaeological narratives about the Iron Age on the margins of academia}

Through performativity and embodiment, participants in re-enactment events such as Luna Celta naturalise a variety of aspects regarding archaeological and historical narratives and disseminate them to the public. Moreover, these narratives are far more successful than most of our academic papers, exhibitions or lectures (Holtorf 2005a, 547) (Figure 6). Nevertheless, for most of our colleagues, the greatest concerns that arise in the light of historical re-enactments can be encapsulated in questions such as 'Are they wearing the right type of sword?'. We wonder if this kind of aspect should be the main concern for archaeologists. Can we change our attitude and be more constructive? Undoubtedly, with re-enactment festivals we can approach audiences we could never reached through museums or other conventional outreach strategies (Daugbjerg 2019). Therefore, instead of complaining about inaccuracies in the use of certain types of swords or necklaces, we should strive to learn more from re-enactments about successful strategies for making an impact on the public and disseminating our archaeological narratives among lay audiences.
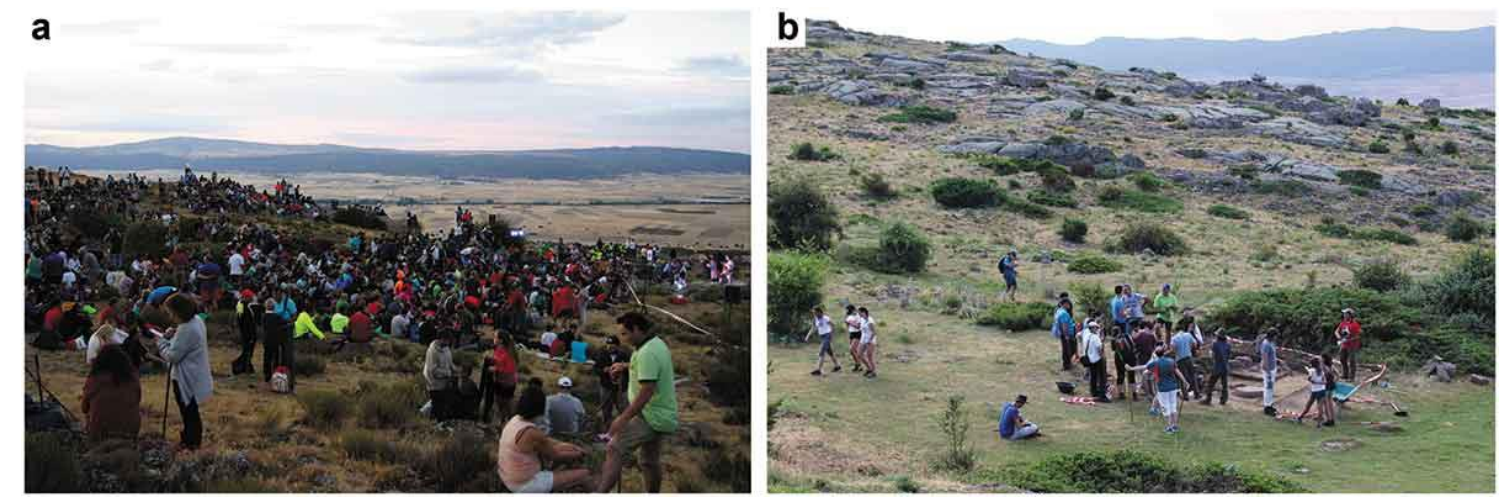

Figure 6. Public inside the oppidum of Ulaca. (a) During the Luna Celta festival 2016. (b) An open day at the excavations carried out in 2018 (photographs by Jesús Rodríguez-Hernández)

We can of course consider programmes of complementary talks. However, if people have to choose from dozens of different activities during the festival, including battles, feasting, drinking beer from animal horns, etc., almost nobody will attend a formal lecture. In fact, some lectures were given by scholars in the first editions of the Luna Celta festival, but they are no longer organised because very few people attended them, as members of the organisation explained to us. 6 Therefore, we need to explore different ways of engaging with people who are interested in the Iron Age, but prefer experiencing it rather than listening to formal and (sometimes) boring top-down academic discourses (Hill 1989).

The pre-Roman communities of central Iberia are normally represented hierarchically at reenactment festivals such as Luna Celta. There are always indigenous leaders who are depicted as a kind of all-powerful king and they are accompanied by male warriors. The indigenous peoples are always depicted as a unified whole, with no variations among them, other than different clothes or banners for the different tribes who take part in the tribes contest. Therefore, this is the historical-cultural view of the Iron Age that prevails (James 1993, 53). Why is that so at a time when archaeological discussions are delving more profoundly into regional diversity and non-hierarchical interpretations of Iron Age societies are gaining space within the academic debates? 
Some of the current interpretations reject the uncritical use of Roman ethnonyms for indigenous communities as ethnic and political realities in the Iron Age of western Iberia (López Jiménez 2004; Sánchez Moreno 2009; Salinas de Frías 2011), as has also been argued elsewhere (e.g. Moore 2011). Although participants organise themselves in tribes (such as Veleaittones, Totem or Villanium) during the re-enactment, those are conceived as some kind of organic division within the Vettones aiming to gather groups of family or friends together. However, at the Luna Celta festival nobody questions that the Vettones were a cultural, social, political and ethnic entity before the influence of Carthage or Rome over these territories. The most recent academic narratives are far more complex and they have the ability to enrich the public understanding of the pre-Roman past. Also, and most importantly, they would enhance the multicultural and multi-ethnic reality of our present-day society (Popa 2019, 260), against nostalgic discourses of a homogeneous national culture and heritage fostered by right-wing populist political parties (Kaya 2019). We may recall here the recent controversy played out on social media following Mary Beard's assertions about a multicultural and multiracial Roman Britain. 7 However, these recent narratives are probably not easily available to the public in central Spain, as they are sometimes written in English and published in fancy journals with high impact indexes and high access fees!

Where do the participants in Luna Celta gather the information they need to build the bottomup narratives that make up the re-enactment? Unlike academic interpretations, New Age stories and pseudo-archaeology are perfectly accessible to them through the internet (Alonso González 2016, 494). Dozens of blogs, Facebook groups and Twitter accounts spread amateur texts and images of a 'Celtic-Barbarian assemblage' (González Álvarez and Alonso González 2013) for the central Iberian Iron Age, along with Wikipedia, where very few academics add and edit content (Grillo and Contreras 2019). We archaeologists should consider coming out of our ivory towers and getting involved in these open spaces for being part of the conversation, and pointing out new questions and sources. As González Ruibal, Alonso González, and Criado Boado (2018) have recently proposed, we have to defend our expert knowledge in the public arena, teaching what we know about past societies, although in constant dialogue with local communities to learn about their concerns and perspectives. However, we can go further. What if we get involved in organising re-enactments, promoting changes in the cultural representations? We are not talking about imposing our academic views on the public, but instead working alongside the people and taking on responsibilities in the organisation. What if we could get involved in reenactments as part of our commitment to local stakeholders in the area of the sites we study? Could this make a difference? We think it could.

\subsection{Vettones, tourism and cultural heritage resource management}

It is fair to have some concerns about the ideological motivations behind some of these reenactment festivals or the commodification of heritage and history linked to touristification (Handler and Gable 1997; Comaroff and Comaroff 2009). For example, we can perceive some implications from the political agenda of several stakeholders at the Luna Celta festival. Business-led interests are also quite clearly behind the support from local tourism entrepreneurs. Should we see this just as a problem? We think it could become an opportunity that would indeed will bring new commitments and risks for the scholars involved. Is it wrong for archaeologists to accept funding from private companies or foundations? While the festival budget at Solosancho is $16,000 €$, an economic return of $150,000 €$ has been estimated (Miguel 2017). The event is a well-funded context in which the relevance of archaeological and historical narratives is out of the question, and it involves thousands of participants and visitors. Why we should disregard these events in our public outreach strategies? This position would not involve ignoring the social and political conflicts that come to the surface at re-enactments. Instead, we should delve more deeply into our examination of these events as scenarios for engaging public archaeology and critical heritage studies with contemporary issues, as the scriptwriters of the 
Luna Celta play demonstrate every year, since they easily connect some aspects related to the Vettones with current public debates, such as gender inequality or the intrusion on people's privacy linked to the widespread of smartphones and social networks.

The success of historical re-enactments such as Luna Celta should be linked to the growing public demand for quality tourism connected to Iron Age archaeological heritage in this region. With this in mind, the regional institutions have recently funded and launched a programme that includes free guided tours of the area's main archaeological sites and heritage resources during the summer, at weekends and on public holidays (Camarero Jiménez 2019), including sites such as Ulaca. These actions emphasise the awareness within the regional institutions of the potential of archaeotourism as a sustainable alternative for local economies facing rural depopulation. Our ethnographic research at the re-enactment shows how the Luna Celta festival has promoted this perception and we can therefore assume that the success of the historical re-enactment has driven cultural heritage resource management governance in this region.

\subsection{Ancestors or local landscapes?}

As archaeologists we can make the most of the resources already available at re-enactment festivals. The plays, the parades and the market at Solosancho show domestic and artisanal activities, while the participants make and use all sorts of pre-Roman objects during the festival. What if we collaborate with them by organising a guided tour explaining the pre-Roman agrarian economy, their built environment, or the importance of households in the interpretation of gender and social inequality? No doubt a few anachronistic things will annoy us, for example, corn in the walls of the huts, Viking helmets or Game of Thrones music. But if we get involved with a positive attitude, the public may come to see that archaeology has something positive to tell them about the Iron Age, beyond commodified New Age discourses and pseudoarchaeology.

The way people lived and worked the land in the past created the cultural landscapes we know today (Sauer 1925). This reflection is not present at Luna Celta and we should be responsible for introducing it. Therefore, we consider it necessary to bring about a change in the dissemination strategy of archaeological projects, to connect the people of the present with the societies of the past through the landscape, rather than though improbable ancestors (Guichard 2017, 109110). This closer relationship with our predecessors through cultural landscapes could bring about a better integration of all the inhabitants in a certain area, including migrants or locals not previously interested in history (in the sense of grand historical narratives talking only about kings, battles, empires and powerful characters), as everyone contributes to the construction of the landscape in which they live (Ingold 2000). It would also prevent the tendency of reenactments to collapse temporalities (Agnew 2007, 309), leading to a dangerous historical continuity between our pre-Roman ancestors and the people of today, which could be exploited by nationalist movements (e.g. Dietler 1994; Díaz-Andreu 1995; Ruiz Zapatero 1996).

\section{Conclusion}

Looking at the case study analysed in this paper, we can consider historical re-enactments as prominent socio-cultural contexts for reflecting on the public perception of archaeological and historical narratives, in addition to their role in shaping contemporary identities, boosting tourism and promoting public awareness of cultural heritage conservation. These events also allow us to explore the role played by materiality in the shaping of 'bottom-up' historical narratives with the non-active participation of academics or scientists. In this way, the (performed) Iron Age becomes a grand arena for the negotiation and resolution of contemporary issues regarding gender and class divisions, the commodification of cultural heritage, and the shaping of regional and national identities. Archaeologists and heritage 
scholars - among other social scientists - should not miss the opportunity to analyse these topics at historical re-enactments, considering the public impact that our disciplines can have in Western societies. Thus, we need to reflect critically on our dissemination strategies, increase our effort in public outreach and engagement with local communities, and stop neglecting the political implications triggered by a growing interest in archaeological narratives and the heritagisation processes attached to them, as we can observe in our case study. Indeed, if scholars do not conduct these analyses informed by the scientific rigour that must sustain our inquiries, somebody else may eventually do it following their own agenda (Ruiz Zapatero 2013,191).

\section{Acknowledgments}

This research has been developed in the framework of the REFIT project (Resituating Europe's First Towns - https://www.refitproject.com/). We are extremely grateful to our interviewees for their kind participation and to Jesús Álvarez-Sanchís for his support. Comments and suggestions provided by the anonymous reviewers were extremely helpful for clarifying the manuscript.

\section{Disclosure statement}

No potential conflict of interest was reported by the authors.

\section{Additional information}

\section{Funding}

This work was supported by the MINECO under Grants number (HAR2015-65994-R and PCIN2015-022, through the European Union, JPI-Heritage Plus initiative).

\section{Notes on contributors}

Jesús Rodríguez-Hernández is a postdoctoral researcher at the Complutense University of Madrid and co-director of the fieldwork project on the oppidum of Ulaca (central Spain). He is an archaeologist whose particular interests lie in the Iron Age societies of Central and Western Europe, cultural landscapes and the public understanding of archaeological heritage.

David González-Álvarez is a postdoctoral researcher at the Institute of Heritage Sciences (Incipit), CSIC in Santiago de Compostela. He currently holds a Juan de la Cierva-Formación fellowship (2019-2021) to investigate the biographies of cultural landscapes in upland environs combining the integrated study of archaeological, palaeoenvironmental and ethnographic datasets. He also explores the social and political implications of archaeological research for contemporary society.

\section{Notes}

1. Following McManamon (1991), we need to emphasise diversity among the people involved in these festivals as members of the public, organisers and participants.

2. The videos of the 2017-2019 plays (in Spanish) are available at: https://www.youtube.com/user/msserret/videos?disable_polymer=1.

3. Interestingly, the famous 'wheel of pain' scene in the film directed by John Milius was shot at Solosancho, which is a source of pride among the middle-aged and older people of the village (https://www.diariodeavila.es/noticia/ZDF86C8DC-97C2-E42F54A651C068574B18/20140720/conan/abulense). 
4. The video of the TV programme (in Spanish) is available at: https://www.youtube.com/watch?v=C69zDDb7984.

5. The video (in Spanish) is available at: https://www.youtube.com/watch?v=4YnUgLhBT6M.

6. While we were writing this manuscript, one of us $(\mathrm{JRH})$ gave a lecture as part of the official programme of the 2019 Luna Celta festival. The talk was attended by approximately 50 people. In contrast, the crowds following the parades through the market could be counted in their thousands.

7. See Boseley, S.: 'Mary Beard abused on Twitter over Roman Britain's ethnic diversity', The Guardian, 6 August 2017: https://www.theguardian.com/uk-news/2017/aug/06/mary-beard-twitter-abuseroman-britain-ethnic-diversity (last accessed: 05/07/2019); Philo, J.-M.: 'Mary Beard is right, Roman Britain was multi-ethnic - so why does this upset people so much?', The Conversation, 9 August 2017: http://theconversation.com/mary-beard-is-right-roman-britain-was-multi-ethnic-so-whydoes-this-upset-people-so-much-82269 (last accessed: 05/07/2019).

\section{References}

AA. VV. 2005. El descubrimiento de los vettones. Los materiales del Museo Arqueológico Nacional. Catálogo de la exposición. Ávila: Institución Gran Duque de Alba.

Agnew, V. 2007. "History's Affective Turn: Historical Reenactment and Its Work in the Present." Rethinking History: The Journal of Theory and Practice 11 (3): 299-312. doi:10.1080/13642520701353108.

Almagro-Gorbea, M., M.Mariné, and J. R.Álvarez-Sanchís, eds. 2004. Celtas y Vettones. 4th ed. Ávila: Institución Gran Duque de Alba-Real Academia de la Historia.

Alonso González, P. 2016. "Between Certainty and Trust: Boundary-Work and the Construction of Archaeological Epistemic Authority." Cultural Sociology 10 (4): 483-501. doi:10.1177/1749975516640569.

Alonso González, P., and D.González Álvarez. 2013. “Construyendo el pasado, reproduciendo el presente: Identidad y arqueología en las recreaciones históricas de indígenas contra romanos en el Noroeste de España." Revista de Dialectología y Tradiciones Populares 68 (2): 305-330. doi:10.3989/rdtp.2013.02.013.

Álvarez-Sanchís, J. R. 2003a. Los señores del ganado. Arqueología de los pueblos prerromanos en el occidente de Iberia. Madrid: Akal.

Álvarez-Sanchís, J. R. 2003b. Los Vettones. 2nd ed. Madrid: Real Academia de la Historia.

Álvarez-Sanchís, J. R. 2005a. "Oppida and Celtic Society in Western Spain." e-Keltoi 6: 255285. http://www4.uwm.edu/celtic/ekeltoi/volumes/vol6/6 5/alvarez sanchis $65 . \mathrm{html}$

Álvarez-Sanchís, J. R. 2005b. Verracos. Esculturas zoomorfas en la provincia de Ávila. Ávila: Institución Gran Duque de Alba.

Álvarez-Sanchís, J. R. 2006. Guía arqueológica de castros y verracos. Provincia de Ávila. Ávila: Institución Gran Duque de Alba.

Álvarez-Sanchís, J. R., and F. J.González-Tablas. 2005. Vettonia. Cultura y Naturaleza. Ávila: Institución Gran Duque de Alba.

Álvarez-Sanchís, J. R., C.Marín, A.Falquina, and G.Ruiz Zapatero. 2008. "El oppidum vettón de Ulaca (Solosancho, Ávila) y su necrópolis." In Arqueología Vettona. La Meseta Occidental en la Edad del Hierro, edited by J. R.Álvarez-Sanchís, 338-361. Alcalá de Henares: Museo Arqueológico Regional.

Álvarez-Sanchís, J. R., and J.Rodríguez-Hernández. 2016. "Engagement Strategies for Late Iron Age Oppida in North-Central Spain." Complutum 27 (2): 401-415. doi:10.5209/CMPL.54753.

Appleby, G. A. 2005. "Crossing the Rubicon: Fact or Fiction in Roman Re-enactment." Public Archaeology 4 (4): 257-265. doi:10.1179/pua.2005.4.4.257.

Ayán Vila, X. M. 2014. "El capital social del patrimonio arqueológico. La gestión para el desarrollo y la participación de las comunidades locales." In El pasado en su lugar. 
Patrimonio arqueológico, desarrollo y turismo. III Jornadas de debate del Museu de Prehistòria de València, edited by J.Vives-Ferrándiz Sánchez and C.Ferrer García, 139176. Valencia: Museu de Prehistòria de València.

Barril Vicente, M. M., and E.Galán Domingo, eds. 2007. Ecos del Mediterráneo: El mundo ibérico y la cultura vettona. Ávila: Institución Gran Duque de Alba.

Burillo, F., P.Burillo, and P.Segurado. 2009. "De la investigación a la escuela: "Segedadenoche". Una reinterpretación teatralizada de la cosmogonía celtibérica." Complutum 20 (2): 195210.

Busquets Artigas, S. 2009. "Tarraco Viva: Cómo disfrutar del Imperio Romano en pleno siglo XXI." Clío: Revista de Historia 91: 56-63.

Camarero Jiménez, I. 2019. "Turismo de calidad para afrontar el reto demográfico." Diario de Ávila, 9 October. https://www.diariodeavila.es/Noticia/ZE2C62F55-F7DD-BA51124998070FF12851/201910/Turismo-de-calidad-para-afrontar-el-reto-demografico

Collis, J. 2008. "The Vettones in a European Context." In Arqueología Vettona. La Meseta Occidental en la Edad del Hierro, edited by J. R.Álvarez-Sanchís, 62-77. Alcalá de Henares: Museo Arqueológico Regional.

Comaroff, J. L., and J.Comaroff. 2009. Ethnicity, Inc. Chicago: University of Chicago Press.

Cortadella, J. 2011. "Los grupos de recreación histórica (historical re-enactment)." In La guerra en la Antigüedad desde el presente, edited by J.Vidal and B.Antela, 91139. Zaragoza: Libros Pórtico.

Crang, M. 1996. "Magic Kingdom or a Quixotic Quest for Authenticity?" Annals of Tourism Research 23 (2): 415-431. doi:10.1016/0160-7383(95)00070-4.

Daugbjerg, M. 2014. "Patchworking the Past: Materiality, Touch and the Assembling of 'Experience' in American Civil War Re-enactment." International Journal of Heritage Studies 20 (7-8): 724-741. doi:10.1080/13527258.2013.848820.

Daugbjerg, M. 2019. "Re-enactment and Engagement." In The Encyclopedia of Archaeological Sciences, edited by S. L.López Varela. doi:10.1002/9781119188230.saseas0499.

De Groot, J. 2009. Consuming History: Historians and Heritage in Contemporary Popular Culture. Abingdon-New York: Routledge.

Del Molino, S. 2016. La España vacía. Viaje por un país que nunca fue. Madrid: Turner.

Díaz Santana, B. 2002. Los celtas en Galicia: Arqueología y política en la creación de la identidad gallega. Noia: Toxosoutos.

Díaz-Andreu, M. 1995. "Archaeology and Nationalism in Spain." In Nationalism, Politics, and the Practice of Archaeology, edited by P. L.Kohl and C.Fawcett, 39-

56. Cambridge: Cambridge University Press.

Dietler, M. 1994. "'Our Ancestors the Gauls': Archaeology, Ethnic Nationalism, and the Manipulation of Celtic Identity in Modern Europe." American Anthropologist 96 (3): 584605. doi:10.1525/aa.1994.96.3.02a00090.

Fabián García, J. F. 2004. "Recuperación, rehabilitación y difusión del Patrimonio Arqueológico de Ávila." In Actas. Puesta en valor del Patrimonio Arqueológico en Castilla y León, edited by J.Del Val Recio and C.Escribano Velasco, 25-38. Salamanca: Junta de Castilla y León.

Fabián García, J. F. 2006. Guía de los castros visitables en el entorno de Ávila. Ávila: Institución Gran Duque de Alba.

Fabián García, J. F. 2008. "La arqueología y el público en los yacimientos vettones de Ávila y Salamanca." In Arqueología Vettona. La Meseta Occidental en la Edad del Hierro, edited by J. R.Álvarez-Sanchís, 424-439. Alcalá de Henares: Museo Arqueológico Regional.

Fernández Ramos, M. Y., P.Cabezas Pascual, C.Belloso Martín, and L. A.Diez Martín. 2018. “'Las recreaciones históricas en Aragón': Análisis y diseño de un producto turístico al servicio del desarrollo local." In VI Foro Internacional de Turismo Maspalomas Costa Canaria. Congreso Internacional Destinos Turísticos Inteligentes, edited by J. M.Benítez Del 
Rosario, A.González Molina, C. B.Eyzaguirre, and L. H.López, 247-260. Las Palmas de Gran Canaria: Universidad de Las Palmas de Gran Canaria.

Fewster, K. J. 2007. "The Role of Agency and Material Culture in Remembering and Forgetting: An Ethnoarchaeological Case Study from Central Spain." Journal of Mediterranean Archaeology 20 (1): 89-114. doi:10.1558//jmea.2007.v20i1.89.

Folgado Fernández, J. A., J. M.Hernández Mogollón,and A. M.Campón Cerro.2016.“Eventos turísticos basados en ambientaciones yrecreaciones Históricas. Un análisis en Extremadura." International Journal of Scientific Management and Tourism 2 (3):81-97.

González Álvarez, D., and P.Alonso González. 2013. “The 'Celtic-barbarianAssemblage': Archaeology and Cultural Memory in the Fiestas de Astures yRomanos, Astorga, Spain." Public Archaeology 12 (3): 155-180.doi:10.1179/1465518714Z.00000000040.

González Reboredo, X. M. 2001. "A construcción de referentes de identidade etno-nacional. Algunhas mostras sobre Galicia." In Etnicidade e Nacionalismo. Actas do Simposio Internacional de Antropoloxía, edited by X. M.González Reboredo, 201-247. Santiago de Compostela: Consello da Cultura Galega.

González Ruibal, A., P.Alonso González, and F.Criado Boado. 2018. "Against Reactionary Populism: Towards a New Public Archaeology." Antiquity 92 (362): 507-515. doi:10.15184/aqy.2017.227.

González-Tablas, F. J., and M.Mateos Benito. 2004. Vettones. Guía infantil de castros y verracos. Ávila: Institución Gran Duque de Alba.

Grillo, K. M., and D. A.Contreras. 2019. "Public Archaeology's Mammoth in the Room: Engaging Wikipedia as a Tool for Teaching and Outreach." Advances in Archaeological Practice 7 (4): 435-442. doi:10.1017/aap.2019.8.

Guichard, V. 2017. "Bibracte: Le paysage au cœur du projet de site/Bibracte: Die Landschaft im Zentrum des Projekts der archäologischen Stätte." In Paysages entre archéologie et tourisme/Landschaften zwischen Archäologie und Tourismus, edited by C.Dunning Thierstein and E.Dunning, 102-113. Biel/Bienne: ArchaeoTourism.

Hamilakis, Y. 2011. "Archaeological Ethnography: A Multitemporal Meeting Ground for Archaeology and Anthropology." Annual Review of Anthropology 40: 399-414. doi:10.1146/annurev-anthro-081309-145732.

Handler, R., and E.Gable. 1997. The New History in an Old Museum: Creating the past at Colonial Williamsburg. Durham, NC: Duke University Press.

Herrero Acosta, X., and X. M.Ayán Vila. 2016. "De las trincheras al museo: Sobre el reciente proceso de patrimonialización de la Guerra Civil española en Euskadi." In Lugares de memoria traumática. Representaciones museográficas de conflictos políticos y armados, edited by I.Arrieta Urtizberea, 99-122. Bilbao: Universidad del País Vasco.

Hill, J. D. 1989. "Re-thinking the Iron Age." Scottish Archaeological Review 6: 16-24.

Hingley, R., C.Bonacchi, and K.Sharpe. 2018. “'Are You Local?' Indigenous Iron Age and Mobile Roman and Post-Roman Populations: Then, Now and In-Between." Britannia 49: 283-302. doi:10.1017/S0068113X18000016.

Holtorf, C. 2005a. "Beyond Crusades: How (Not) to Engage with Alternative Archaeologies." World Archaeology 37 (4): 544-551. doi:10.1080/00438240500395813.

Holtorf, C. 2005b. From Stonehenge to Las Vegas: Archaeology as Popular Culture. Walnut Creek: AltaMira Press.

Holtorf, C. 2007. Archaeology Is a Brand! The Meaning of Archaeology in Contemporary Popular Culture. Oxford: Archaeopress.

Ingold, T. 2000. The Perception of the Environment. Essays on Livelihood, Dwelling and Skill. London: Routledge.

James, S. 1993. Exploring the World of the Celts. London: Thames and Hudson. 
Jimeno Martínez, A. 2013. "Numancia: divulgación ygestión." Estudios del Patrimonio Cultural 11: 8-20.

Kaya, A. 2019. Populism and Heritage in Europe: Lost in Diversity and Unity. Abingdon-New York: Routledge.

King, N., and C.Horrocks. 2010. Interviews in Qualitative Research. London: Sage.

Kobiałka, D. 2013. "The Mask(s) and Transformers of Historical Re-Enactment: Material Culture and Contemporary Vikings." Current Swedish Archaeology 21: 141-161.

Kobiałka, D. 2014. "Archaeology and Communication with the Public: Archaeological Open-air Museums and Historical Re-enactment in Action." European Journal of Post-Classical Archaeologies 4: 359-376.

Kristiansen, K. 1996. "European Origins - 'Civilisation' and 'Barbarism'." In Cultural Identity and Archaeology. The Construction of European Communities, edited by P.GravesBrown, S.Jones, and C.Gamble, 138-144. London: Routledge.

López Jiménez, O. 2004. "Las fuentes antiguas y la creación literaria de la Vetonia." Gerión 22 (1): 201-214.

Marín Suárez, C., D.González Álvarez, and P.Alonso González. 2012. "Building Nations in the XXI Century. Celticism, Nationalism and Archaeology in Northern Spain: The Case of Asturias and León." Archaeological Review from Cambridge 27 (2): 11-31.

McManamon, F. P. 1991. "The Many Publics for Archaeology." American Antiquity 56 (1): 121130. doi:10.1017/S0002731600067299.

Merriman, N., ed. 2004. Public Archaeology. London: Routledge.

Meskell, L. 2005. "Archaeological Ethnography: Conversations around Kruger National Park." Archaeologies: Journal of the World Archaeological Congress 1 (1): 81-100. doi:10.1007/s11759-005-0010-x.

Miguel, C. 2017. "El evento celta retorna 150.000 euros a Solosancho." Ávilared, 16 August. https://avilared.com/art/27983/el-evento-celtaretorna-150-000-euros-a-solosancho

Miranda Viñuelas, J. 2008. Ulaca. Una noche alucinante. Girona: Rigau.

Montón Subías, S., and M.Sánchez Romero, eds. 2008. Engendering Social Dynamics: The Archaeology of Maintenance Activities. Oxford: BAR International Series 1862.

Moore, T. 2011. "Detribalizing the Later Prehistoric Past: Concepts of Tribes in Iron Age and Roman Studies." Journal of Social Archaeology 11 (3): 334-360. doi:10.1177/1469605311403861.

Moore, T., V.Guichard, and J. R.Álvarez-Sanchís. 2020. "The Place of Archaeology in Integrated Cultural Landscape Management: A Case Study Comparing Landscapes with Iron Age Oppida in England, France and Spain." Journal of European Landscapes 1: 9-28. doi:10.5117/JEL.2020.1.47039.

Moshenska, G., ed. 2017. Key Concepts in Public Archaeology. London: UCL Press.

Pena Castro, M. J. 2004. "El negocio de la historia en la Feria Medieval de Noia." Sociológica. Revista de pensamiento social 5: 81-100.

Picazo Gurina, M. 1997. "Hearth and Home: The Timing of Maintenance Activities." In Invisible People and Processes: Writing Gender and Childhood into European Archaeology, edited by J.Moore and E.Scott, 59-67. London: Leicester University Press.

Popa, C. N. 2019. "The Responsibility of European Archaeologists." European Journal of Archaeology 22 (2): 255-268.doi:10.1017/eaa.2019.13.

Raposo, P. 2008. "Performando cultura: Recreaciones históricas e interpretaciones patrimoniales." In Patrimonios Culturales: Educación e interpretación. Cruzando límites y produciendo alternativas, edited by X.Pereiro, S.Prado, and H.Takenaka, 7591. Donostia: Ankulegi Antropologia Elkartea. 
Rodríguez-Hernández, J. 2019. Poder y sociedad: El oeste de la Meseta en la Edad del Hierro. Ávila: Institución Gran Duque de Alba.

Rojas Rabaneda, A. 2010. "The Uses of Cultural Heritage in Catalonia: The History Reenactment as Way of Preservation, Exhibition and Local Development." In Heritage 2010. Proceedings of the 2nd International Conference on Heritage and Sustainable Development, edited by R.Amoêda, S.Lira, and C.Pinheiro, 1151-1158. Barcelos: Green Lines Institute for Sustainable Development.

Rojas Rabaneda, A. 2011. "Herramientas y estrategias de difusión del Patrimonio Histórico: Los eventos de recreación histórica en Cataluña." e-rph: Revista electrónica de Patrimonio Histórico, 9. https://revistadepatrimonio.es/index.php/erph/article/view/109/93

Ruiz Zapatero, G. 1996. "Celts and Iberians: Ideological Manipulations in Spanish Archaeology." In Cultural Identity and Archaeology: The Construction of European Communities, edited by P.Graves-Brown, S.Jones, and C.Gamble, 179-195. London: Routledge.

Ruiz Zapatero, G. 2005a. Castro de Ulaca. Solosancho, Ávila. Ávila: Institución Gran Duque de Alba.

Ruiz Zapatero, G. 2005b. "Soria, 'Keltiberoi' - 2004: ¡la historia a la calle!." Complutum 16: 279-286.

Ruiz Zapatero, G. 2006. "The Celts in Spain. From Archaeology to Modern Identities." In Celtes et Gaulois, l'Archéologie face à I'Histoire, 1: Celtes et Gaulois dans l'histoire, I'historiographie et l'idéologie moderne, edited by S.Rieckhoff, 197-218. Glux-enGlenne: Centre archéologique européen.

Ruiz Zapatero, G. 2013. “¿Qué son arqueologías de elite y arqueologías desde abajo?” In La Uni en la calle, edited by A.Gaita, P.Pozuelo Blancas, L.Tejado Montero, and L aMarea, 190191. Madrid: Cooperativa MásPúblico.

Ruiz Zapatero, G., and J. R.Álvarez-Sanchís. 2008. "Los verracos y los vettones." In Arqueología Vettona. La Meseta Occidental en la Edad del Hierro, edited by J. R.Álvarez-Sanchís, 214231. Alcalá de Henares: Museo Arqueológico Regional.

Ruiz Zapatero, G., and N.Salas Lopes. 2008. "Los vettones hoy: Arqueología, identidad moderna y divulgación." In Arqueología Vettona. La Meseta Occidental en la Edad del Hierro, edited by J. R.Álvarez-Sanchís, 408-423. Alcalá de Henares: Museo Arqueológico Regional.

Salinas de Frías, M. 2011. "Las fuentes clásicas y el poblamiento prerromano del occidente peninsular. Problemas de etnicidad y cultura." In Castros y verracos. Las gentes de la Edad del Hierro en el occidente de Iberia, edited by G.Ruiz Zapatero and J. R.ÁlvarezSanchís, 129-157. Ávila: Institución Gran Duque de Alba.

Sánchez Moreno, E. 2000. Vetones: Historia y arqueología de un pueblo prerromano. Madrid: Ediciones de la Universidad Autónoma de Madrid.

Sánchez Moreno, E. 2009. "Vetones y Vettonia: Etnicidad versus ordenatio romana." In Lusitanos y vettones. Los pueblos prerromanos en la actual demarcación Beira Baixa Alto Alentejo - Cáceres, edited by P. J.Sanabria Marcos, 65-81. Cáceres: Junta de Extremadura.

Sauer, C. O. 1925. "The Morphology of Landscape." University of California Publications in Geography 2 (2): 19-53.

Schadla-Hall, T. 1999. "Editorial: Public Archaeology." European Journal of Archaeology 2 (2): 147-158. doi:10.1179/eja.1999.2.2.147.

Ser Quijano, G. D., ed. 2006. Ruta de castros y verracos de Ávila, Salamanca, Miranda do Douro, Mogadouro y Penafiel. Ávila: Institución Gran Duque de Alba.

Smith, L. 2006. Uses of Heritage. Abingdon-New York: Routledge. 
Sørensen, M. L. S. 2009. "Between the Lines and in the Margins: Interviewing People about Attitudes to Heritage and Identity." In Heritage Studies: Methods and Approaches, edited by M. L. S.Sørensen and J.Carman, 164-177. New York: Routledge.

Tully, G., C.Piai, J.Rodríguez-Hernández, and E.Delhommeau. 2019. “Understanding Perceptions of Cultural Landscapes in Europe: A Comparative Analysis Using 'Oppida' Landscapes." The Historic Environment: Policy \& Practice 10 (2): 198-223. doi:10.1080/17567505.2019.1587251.

Vicente Toribio, J. M. D. 2004. La noche de Ulaca.Salamanca: CELYA. 